Monica Maria Martins de Souza ${ }^{1}$

\title{
As interações humanas no espaço social do trabalho homem e empresa em transform/ação
}

Recebido em: 03/12/2012 - Aprovado em: 16/12/2012 - Disponibilizado em: 26/12/2012

\section{Resumo}

As investigações acerca do papel da missão organizacional; - texto mediador sobre o funcionário para que ambos alcancem uma conjunção, busca a compreensão da força da missão sobre o trabalhador. A mediação possibilita ampla coesão nessa relação, de maneira que o funcionário vai além da representação de um papel na aquisição dessa competência. No processo de identificação com a empresa ele se transforma em sujeito, elevado a essa categoria pela ação da missão. O papel do texto da missão comunicação e cultura - é se constituir em sua continuidade, destaca e fala ao funcionário como sujeito. Desta forma, promove-o e determina seu deslocamento, sua hora de acordar, de levantar, de se ligar e desligar - universo simbólico, espaço de tranform/ação. Participa com ele em condições de orientá-lo, de determinar a relação, e todo o tempo, ambos permanecem alerta, vendo e sendo vistos. A missão da empresa integra todos os recursos que o homem precisa para se orientar, ou seja, os vínculos comunicacionais. Entra em sua vida com tamanha impetuosidade que marca o seu cotidiano, governa o seu sentido e a sua presença, mesmo quando ausente. Longe da empresa, o homem mantém sua forma de comunicação e interação, programada por ela: a missão organizacional. Assim nas interações humanas no espaço social do trabalho tanto o homem quanto a empresa se transformam enquanto dançam em um jogo que devora e faz devorar - a norma, por ser transforma/ dor.

Palavras-chave: Missão Organizacional; Aquisição de Competência, Comunicação, Cultura e Universo Simbólico; Vínculos Comunicacionais; Espaço de transform/ ação.

\section{Abstract}

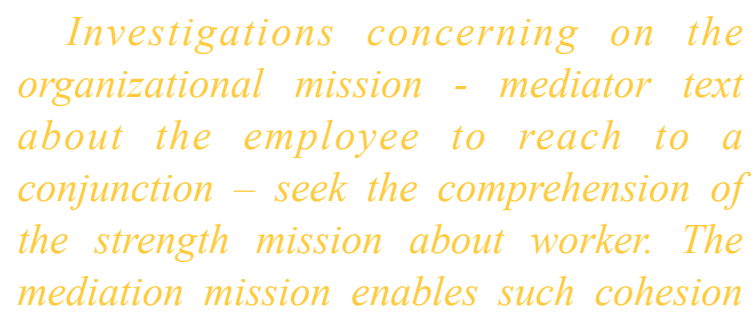

\footnotetext{
${ }^{1}$ Doutora em Comunicação e Semiótica pela PUC/SP. (2005), Mestre em Administração de empresas pelo Mackenzie/SP. (1999). Especialista em Administração. de RH pela UNA. União de Negócios Adm. de BH, MG. (1995), e especialista em Tecnologia Educacional pela UNINOVE SP. (2000), é Psicóloga graduada Newton Paiva de BH/ MG. (1991). Atualmente é Profa convidada pela Pós-graduação do Mackenzie. Desde 2006 é avaliadora INEP. Profa. Dra, Pesquisadora da Faculdade ENIAC, coordena grupos de pesquisa e iniciação científica, organizadora dos Seminários Anuais desde 2009 e da Revista Acadêmica ENIAC PESQUISA. É Profa. Dra. Pesquisadora, coordenadora de Cursos e da Revista Acadêmica Augusto Guzzo das Faculdades Integradas Campos Salles - FICS desde agosto de 2010. Consultora da Euroatlantica Ghesa Brasil Ltda.
} 


\begin{abstract}
in this relationship that the employee goes beyond the representation of a role in the acquisition of competence. In the process of identification with the company he becomes subject to this higher category through the action of the mission. The text role in the mission - communication and culture - be constituted in a continuity, and emphasizes and talks to the employee as the subject. Thus promotes and determines its displacement, time to wake up, get up, turn on and off; symbolic universe and space transformation. Participating with him under conditions of guide him and determine the relationship, and the whole time, both of them remain alerts seeing and being seen. The company mission connects all resources that man needs for guidance - communication links. It comes into your life with such
\end{abstract}

\section{Introducão}

Nesta investigação, propomos-nos a analisar a relação do sujeito, missão da empresa e do funcionário, objeto valor, e a forma como o sujeito possui a competência de promover o reconhecimento do objeto, a despeito da sua diferença, fazendo dele uma parte integrante de si. O corpus, missão, vai abordar o objeto de construção, para dar sentido à sua vida no espaço organizacional. Ele será re/construído a partir dos valores da empresa que serão transmitidos pelo texto da missão. $\mathrm{O}$ funcionário vai ficar contaminado pelas crenças da empresa e vai se despojar de suas próprias crenças.

$\mathrm{O}$ afastamento das próprias crenças é difícil porque elas fazem parte da construção da vida, tanto do sujeito como do objeto. Mas a missão é um sujeito que impetuosity that let a mark in your daily life, governs its meaning and presence, even when absent. The man, far from the company, keeps his communication way and interaction, for her scheduled the organizational mission. Scheduled for her organizational mission. Therefore in human interactions within social work both the man and the company in turn while playing a game which devours and is devoured - rule, because it transforms the pain.

Keywords: Organizational Mission; Acquisition of Competence, Communication, Culture and Symbolic Universe; Links Communicational; transformation space.

intercepta e desperta para o outro, um outro aspecto da vida, e este objeto adquire papel de sujeito pela ação que a missão nele intercede. Esse conceito da reversibilidade sujeito/objeto, o sujeito que faz: fazer pode ser o agente do fazer. No modelo semiótico de Greimas "Da Imperfeição", pensamos na reversibilidade em que temos um objeto com um fazer de sujeito. $\mathrm{O}$ funcionário já possui um saber fazer, mas quando entra na empresa ele vai re/aprender o fazer desta empresa dentro dos seus moldes. Este novo fazer torna-a actante, e ocupa um papel central. Quando temos um actante temos um fazer. E a reunião dos fazeres é que leva à transformação.

A estrutura do percurso narrativo da missão vai produzir os estados transformados em outros estados, aqueles desejados pela empresa. Essa transformação é o que define a narratividade. Há o encadeamento de 
estados e transformações que dão este caráter narrativo às mensagens da missão, no sentido da estrutura dos estados de transformações. Isto é universal. Esta universalidade é uma pressuposição. Todos os textos têm, o seu folclore, seus mitos e na empresa, isso é muito mais intenso. A manifestação textual convoca e reúne sentidos levando o funcionário a reproduzir (não mais criar seu próprio trabalho, mas apenas repetir) no sistema de ordem.

A transformação desejada pela missão considera cada grupo cultural, cada comunidade, pelos seus fazeres, pelas suas ações, pelos seus rituais, pelas suas formas de relacionamento e sua estrutura, os textos da cultura. E o estudo da cultura da empresa, é feito pelos seus textos. E na semiótica estamos tratando a missão como manifestação dessa cultura. E enquanto manifestação textual é construída a partir de valores. Ela retoma o posicionamento a partir da visão de mundo da empresa, um estado no mundo. Não é uma visão individual, a empresa é composta por pessoas que têm suas crenças partilhadas.

A enunciação da missão convoca à aquisição de competência para o poder, saber, fazer, e no espaço organizacional a significação pode ser concretizada ${ }^{2}$. O fenômeno será observado pelo viés da comunicação mediado pelo trabalho, vínculo que enreda homem e empresa, em um jogo de mútua sedução. Para isso, é fundamental considerar a relação da missão com os fatos da cultura ${ }^{3}$ emergindo de signos que ressignificam o comportamento do homem, que, neste espaço, sedado reproduz, fazendo do seu tempo o tempo da empresa, possuído pela narrativa enunciadora que promete a competência de um Deus ${ }^{4}$ e que possibilita a sua plenitude na terra. Pode-se observar aqui a relação estética tratando o imaginário como potência de construção do sujeito, produzindo o simulacro da presença.

O funcionário imbuído da promessa representa um papel no fazer da empresa que o devora. Submetido à mensagem organizacional, promotora da competência cognitiva e sensível, previamente programadas. Sujeito 1- missão da empresa, e sujeito 2 - funcionário, fundemse mediados pelo trabalho, e unificados mais do que em proximidade física. Comungam no espaço de reprodução buscando conjunção.

Compreender o sentido do trabalho como mediador no texto da cultura organizacional $^{5}$ convocado pelo texto "sagrado", a missão, nos faz pensar que o homem dança uma coreografia definida que permite uma única representação possível, a coletiva. O passo de dança

\footnotetext{
2 OLIVEIRA, A.C. LANDOWSKI, E. Do inteligivel ao sensivel, São Paulo, Educ, 1995.

${ }^{3}$ WINKIN, Yves. A Nova comunicação. Da teoria ao trabalho de Campo. Campinas, Papiros. 1998. (Org. Etienne Samain).

${ }^{4}$ HILLMAN, James. Encarando os deuses. São Paulo: Cultrix/Pensamento, 1997.

${ }^{5}$ WEICK K. E. (1985) "The Significance of Corporate Culture." In: Organizational Culture. California: Sage.
} 
"reproduzir" 6, e uma ação mecânica, signo midiático da conjunção.

A missão é o instrumento comunicativo ${ }^{7}$ que determina o ritmo e a performance dos dançarinos em busca da competência, e esse movimento implica na perda da identidade individual que será substituída pela coletiva, condição sinequanon para que a dança se efetue ${ }^{8}$. A empresa acena para o homem com papéis fixos como os dos deuses; e míticos e funcionais como os da sociedade. E ele, seguindo o percurso narrativo, busca aquisição dessa competência divina para se tornar um sujeito de fato e de direito. Nesse espaço não se permitem práticas individuais, existem valores que governam as ações coletivas e as práticas sociais que promovem a coletividade com a qual todos devem se identificar: o coletivo 9 .

Vamos entender aí o conceito saussureano - a relação entre língua e fala, entre história, passado, diacronia e sincronia, presente, entre contexto e texto; que é uma noção de Greimas, quando vai retomar as oposições saussureanas. $\mathrm{Na}$ empresa não há a concepção de língua isolada, individual - ela é sempre coletiva é resultado de acordos sociais. O que move as pessoas dessa comunidade são as crenças, valores superstições e seus emblemas criados como $\log { }^{10}$. Quando pegamos o texto de uma empresa, nos deparamos com a filosofia da empresa. A empresa constrói e se constitui como sujeito, possui uma identidade, da mesma maneira que a escola, a família e a sociedade. Suas regras, normas, são pensadas como coletivas e se relacionam, se articulam segundo esses valores. Não há norma, axiologia, ou ética, separada dessa forma de organização. O homem e a empresa enredados pelo vínculo comunicativo, permeado de normas deflagram atitudes de fidelidade e comprometimento, colocando o trabalho em primeiro lugar ${ }^{11}$, e isso, gradativamente o consome.

As formas de organização da missão são formas estéticas. Como todo arranjo que tem maior ou menor teor de esteticidade é a forma de articulação. Um enredo, uma construção um todo de sentido que o enunciador do desenredo vai trabalhar. Promove a construção da nova identidade do funcionário a partir da identidade do outro: a empresa. Considerando que o outro tem seus arquétipos, seus papéis fixos e seus deuses, e ainda que seus papéis míticos sejam funcionais na sociedade. Cada um dos deuses tem uma função. $\mathrm{O}$ da empresa é a missão, deusa do poder, do saber e do fazer fazer.

Quando o funcionário vai para a empresa, se dirige a esse deus como sujeito e busca a competência deste deus para se tornar competente. Alia-se a este sujeito em um percurso narrativo, que é de aquisição. $\mathrm{O}$ percurso de aquisição provoca uma quebra na normalidade; desestrutura

\footnotetext{
${ }^{6}$ FERRARA, Lucrecia. 2000. Os Significados Urbanos. São Paulo. Edusp/Fapesp

${ }^{7}$ WATZLAWICK, P; BEAVIN, J. e JACKOBSON, D. D. Pragmática da comunicação Humana. São Paulo, Cultrix, 1993.

8 PROSS, Harry, Estructura Simbolica del poder, 1980:36.

${ }^{9}$ LANDOWSKI, E., FIORIN, J. L. O gosto da gente o gosto das coisas. Abordagem semiótica. Trad. Brandão. E.São Paulo: EDUC/PUC, 1997.

${ }^{10}$ LANDOWSKI, E. e OLIVEIRA, A. C. de (eds.), Do inteligivel ao sensivel, São Paulo, Educ, 1995.

${ }^{11}$ KAMPER, D. (1997). O trabalho como a vida, SP: Annablume.
} 
todo o seu conjunto de hábitos e de convenções, reguladores do seu viver. Agora, as práticas individuais desaparecem dando lugar à norma coletiva, governada pelo deus missão. Os seus valores é que vão promover o funcionário e ajudá-lo a se identificar na narrativa. Isso provoca a quebra da normalidade anteriormente estabelecida.

Com a identidade coletiva, ele se transforma e transfere seus valores para outra organização de outra cultura com um conjunto de práticas sociais, distintas. Dois universos diferentes em valores, nas práticas e nas experiências se aproximam e ocorre a organização da prática interativa. A interação dos sujeitos é um grande texto, de troca de projetos, práticos, ideias, valores. Um novo mundo de novos mitos e magias. Duas formas de conhecimento que se integram e constroem a transformação, dirigida, no entanto, pela missão. Greimas em "Da Imperfeição" afirma que todo o mundo cultural é ordenado, e vai ordenar a vida daquele que nela se insere. Assim o é na empresa.

As fraturas da inserção vão aparecer na estrutura do sujeito, no percurso narrativo que vai compondo a sua nova identidade. A troca da identidade anterior pela atual. $\mathrm{O}$ seu tempo passa a ser o tempo da empresa que cria para ele uma rotina devoradora ${ }^{12}$. Esse sistema é estabelecido a priori e o homem responde às suas expectativas, a tua, veste a camisa, adota comportamentos, delimita o seu cotidiano, permitindo que o seu fazer e o seu lazer sejam programados e ditados pela empresa. Inserido e comprometido nesse contexto, acredita que poderá realizar o propósito de ambos e iludido nesse jogo, aliena-se de seus objetivos pessoais e abraça os da empresa como se fossem os seus. Greimas mostra que o evento estético acontece nos comportamentos mais efêmeros, criando significado e sentido. $\mathrm{Na}$ análise semiótica, o significado aparece na narrativização do comportamento. Cada ato adquire novo sentido. O parecer oculta o ser, e na empresa, esta é a possibilidade do homem.

A figuratividade que é o recurso primeiro de um texto é a possibilidade da missão. Suas mensagens sedutoras se colocam nas estruturas do texto, e as formas de reconhecimento social, situam o texto no mundo organizacional. Aparece inicialmente de forma des/pretensiosa e fala sem causar estranhamento. Faz o sujeito percorrer a civilização através dele, como parte dele, re/conhecendo nele, características do seu ser. Aparece de modo natural, e por conseguinte, marca temporalidade. A narrativa é um encadeamento.

$\mathrm{O}$ estado anterior do funcionário era composto pelo comportamento de um fazer diferente. Uma vez inserto, a missão produz nele as transformações, e o seu fazer se modifica. Ela gera um ato que afeta o sujeito que se transforma de objeto em outro sujeito, parece automática a re/ gravação e a ordenação dos atos e fazeres anteriores. Ele sabia um fazer diferente, a transformação ocorreu na mudança do ritmo, no ato, no formato, na constância. Este novo fazer aparece timidamente. E vai adquirindo um ritmo marcado por outra constância.

A substituição da identidade individual pela coletiva, e a mudança de constância, no ritmo de vida e de trabalho do funcionário, provoca uma ruptura. A 
ruptura ocorre naquele que sofre a ação. A convocação sensorial do encadear das ordens sensoriais da missão provoca a tensão. A distensividade ocorre, mesmo havendo o desejo do funcionário de inserirse nesse meio que ele deseja.

$\mathrm{Na}$ adaptação da nova identidade no novo ritmo, se faz sentir a suspensão tensiva do seu fazer anterior. Ele gera uma anormalidade do comportamento, porque agora ele tendo sido sancionado positivamente, não pode mais errar. $\mathrm{Na}$ quebra da rotina instala-se a figura da dis/ tensividade. Ele perde o equilíbrio anteriormente estabelecido e precisa se apoiar em novos costumes. Este evento extraordinário, a sanção positiva, e o desejo de aí permanecer, afeta o sujeito nos seus sentidos, audição, visão, sentido corpóreo pela orientação, pelo movimento.

Quando há suspensão do tensivo, a suspensão da rotina anteriormente marcada, muda o percurso do sujeito, Essa mudança é sentida no corpo, no que há de mais significante, no equilíbrio. "O lampejo do medo do não saber e do medo de não fazer correto provocando a exclusão, é que desencadeia a fratura". Ser sancionado positivamente pela empresa é o deslumbrar e o medo da exclusão é ofuscamento da luz. O lampejo do medo ofusca, não deixa ver, não deixa raciocinar, faz sentir, a quebra de normalidade.

O fazer da missão transformou o objeto em sujeito, ele saiu da disjunção para a conjunção, lugar do poder e status, que para ele significa valor. Agora o medo, ação desta distensão e evento extraordinário, leva à transformação do sujeito. determinando o comportamento de um corpo e a atitude de um devir do sujeito $^{13}$.

A missão doa ao sujeito a competência tornando-o mais capaz na sua cotidianidade, sem a presença de eventos fora do seu controle. Agora ele pode figurativizar, concretizar e materializar o que estava nos seus sonhos e esperanças. A empresa através da missão ordena os mecanismos construídos e valorados socialmente. Ordena também o seu cotidiano neste mundo definido e marcado, no qual só goza do respeito social aquele que está vinculado a uma empresa, que possui cargos, altos salários e bens que denunciam satus. A articulação de valores como reconhecimento social, o leva a fazer o quadrado semiótico.

No conjunto do texto temos a vida do funcionário aceito pela empresa, como eufórico ou disfórico. Chegamos às oposições a partir das isotopias que vão ser reiteradas. É a semântica; quando temos a figuratividade e a tematicidade. Ele vai adquirindo os atributos da empresa através da missão, esta vai construindo nele a sua figuratividade, e a partir deste atributo define o seu ser, suas formas e seus sentidos. São temas concretizados pelas normas organizacionais, e a normatização da empresa, que por um lado tira-lhe a identidade individual por outro, liberta o indivíduo da opressão e da exclusão social. Este trabalho ocorre paralelamente na figuratividade.

O tema: missão da empresa e funcionário é uma abstração a partir da figuratividade que está mais perto e mais concreto. A identidade da empresa assumiu o papel social do homem, através da

${ }^{13}$ OLIVEIRA, A. C., Eric Landowski, Caderno de Discussão do Centro de Pesquisa Sociossemiótica PUC: COS - USP: FFLCH - CNRS: PARIS, 2003. 
missão. No nível profundo temos uma oposição semântica identidade $\mathrm{x}$ alteridade. O nível discursivo trabalha no texto da missão que põe em discurso o nível sintático, o trabalho do enunciador. Este trabalho do enunciador aciona os mecanismos sintáticos de instauração, do enunciador e do enunciatário.

Os valores da empresa são delegados aos que nela trabalham. A comunicação se dá entre quem enuncia e aquele para quem é dirigida a enunciação; um dos conceitos mais importantes da semiótica porque são as artimanhas, as astúcias da enunciação, que permitem ver quem enuncia, como é que enuncia e a maneira de enunciar. $\mathrm{O}$ texto da missão faz fazer e diz como fazer, quando e onde, pela maneira de mostrar, plano de expressão e fazer ouvir.

O enunciado define a disposição dos atores em uma figuratividade sinestésica, o sujeito é completamente tomado e não consegue resistir ao chamado do objeto, confundindo-se com ele, mas a sua competência é doada a ele que se transforma em sujeito. A gestualidade do corpo instaurada, desde que inserto no texto da empresa, adquire um ritmo específico e marcado, o seu comportamento e linguagem, postura e forma de expressão, já não são mais do seu domínio $^{14}$. Ambos, sujeito e objeto, agora, sujeito, buscam a conjunção na ilusão de encontrar a plenitude. A missão afasta o desconhecido (a exclusão do homem deste meio), para concretizar a conjunção, porém esta é uma eterna construção.
A ênfase na conjunção, no fazer parte de, no relacionar com o sujeito, tem a função de desconstruir a ideia do afastamento, figurativizado com a ênfase de que esse é o lugar onde se pode realizar o desejo de poder, que possibilita o saber e o fazer, e isso afasta a angústia da não pertença, a fratura. A possibilidade de construção do sujeito potencializa, exalta a fidelidade, a lealdade, a dedicação incondicional como objeto de apreensão estética. O sujeito semiótico tem vontade de conjunção. Ele se coloca no mundo da cultura da empresa, adota seus valores, constrói novas relações, encena e se faz contemplar enquanto simulacro ${ }^{15}$.

\section{Missão em análise}

Pensando analisar este simulacro, buscamos informações sobre a missão de uma empresa em um site, de domínio público, observando alguns fragmentos e seus desdobramentos.

Na empresa escolhida, uma indústria de alimentos, destacamos a seguinte narrativa:

\section{Cargill}

Figura 1

"A empresa iniciou o século 21 com um novo desafio: tornar-se, na próxima década, a principal provedora de soluções para nossos clientes dos setores agrícolas e de alimentos". Reconhecemos que somente

14 MORIN, E. Introdução ao Pensamento Complexo. Lisboa: Inst. Piaget, 1990. “a convivência, só é possível em virtude da submissão dos indivíduos".

${ }^{15}$ MORIN, E. O Método/ O conhecimento do conhecimento. Porto Alegre. Sulina, 1999, "todo indivíduo tem importância na empresa para a qual colabora com sua própria complexidade, sua visão do mundo, seus projetos pessoais, suas atitudes imprevisíveis, suas estratégias, sua dinâmica de evolução. Para ele a empresa é "a sua" representação da empresa". 
obteríamos sucesso em nosso negócio se criássemos valores diferenciados para nossos clientes. Levamos para esta jornada; nossos tradicionais pontos fortes que são integridade e confiabilidade. Também trazemos nosso conhecimento e experiência, acumulados pela nossa atuação nas mais diversas localidades, produtos e serviços. A partir desta base, formaremos relacionamentos mais sólidos com cada cliente, possibilitando:

Explorar necessidades não atendidas;

Descobrir juntos as melhores maneiras de atendê-las;

Criar soluções únicas e valorizadas; e

Entregá-las de maneira confiável.

Adotamos, como empresa, esta missão e ela reflete como vemos o futuro.

O nosso novo logotipo e o sistema de identidade corporativa, também representam as aspirações da nossa companhia. "As mudanças são as consequências dos poderosos símbolos de uma empresa mais dinâmica, acessível e inovadora na qual estamos nos tornando."

O estilo do logotipo é dinâmico e indica movimento em direção ao futuro. $\mathrm{O}$ nome da empresa em forma de berço - aquele que acolhe, é sobreposta por uma gota em movimento e em direção para adiante indicando movimento, caminhando em um sentido. É colocado em perspectiva diacrônica, inscreve-se como agente e testemunha do seu próprio devir. Aquele que atua acolhe e assiste. Exalta o investimento da empresa no crescimento, visando aumentar a participação no mercado. Reduzido e formatado no alto da página acima do texto da missão e das metas, o logotipo indica pretensão à prospecção, de mágico. Aquele que faz, faz fazer e assiste o fazer do outro. Seguido do enunciado da missão e reduzido ao estado de mensagem no papel é o equivalente simbólico metonímico ou metafórico do outro.

Um sujeito figurado, um simulacro inscrito no espaço retangular que equivale ao ausente da imagem. Acompanhado da visão e da missão, confere sentido ao enunciado ${ }^{16}$. Sujeito e objeto são caracterizados neste contexto como entidades chamadas a entrar em conjunção pela estratégia das suas posições actanciais. O jogo de sedução aqui realizado é analisável como processo recursivo, fundado na reprodução especular de posturas adotadas alternadamente, enunciação e enunciado tem a intenção de atualizar competência. No logo, o contraste das cores: verde/preto/ amarelo, em seu formato reduzido, saltam da superfície do papel em uma abstração esquematizante, produzindo o simulacro da presença da empresa com sua narratividade ${ }^{17}$.

"A nossa visão expressa as aspirações coletivas das pessoas que aqui trabalham. Ela nos unifica, dirige nossos esforços e nos diferencia das outras empresas. Possui quatro elementos: nosso objetivo: é ser líder mundial em alimentos. Nossa missão: criar valores diferenciados. Nossa abordagem: sermos dignos de confiança, criativos e empreendedores. Nossas medidas de desempenho: funcionários engajados, clientes satisfeitos, comunidades enriquecidas e crescimento rentável."

O apelo mítico e apelativo da visão, como a concretização de uma verdade

\footnotetext{
16 TEIXEIRA, L., "Relações entre o verbal e o não verbal: pressupostos teóricos", in Caderno de discussão do VII Colóquio do Centro de Pesquisas Sociossemióticas, 2000, pp. 415-426.

${ }^{17}$ OLIVEIRA, A. C., LANDOWSKI, E. Caderno de Discussão do Centro de Pesquisa Sociossemiótica. São Paulo: ed. CPS. 2002
} 
coletiva, enaltece valores sociais, humanos e profissionais, como a expressão "as aspirações coletivas das pessoas que aqui trabalham". Possui grande poder de persuasão18 e instiga o sentimento subjetivo do animal simbólico, explora uma forma de conhecimento significativo para o humano e remonta à memória do nômade que só sobrevive como grupo.

"Nosso Objetivo é "Alimentar as pessoas" reflete nosso enfoque agrícola e em alimentos e a ideia mais ampla de melhorar a qualidade de vida das pessoas. Isto também quer dizer que o nosso objetivo fundamental é atrelar nosso conhecimento e energia para oferecer produtos e serviços necessários para a vida, saúde e crescimento. Implica em cumprir um leque de expectativas, desde aprimorar a produtividade agrícola até melhorar os alimentos para promover um desenvolvimento econômico sustentável. Também transmite uma cultura de alimentar com base na confiança, valorização das relações e na realização de todo o seu potencial.".

Pelo procedimento de textualização, "O seu objetivo é Alimentar as pessoas", o discurso verbal procura ser atraente para o enunciatário. $\mathrm{O}$ enquadramento e a inserção da informação são elementos semióticos capazes de promover e/ou fazer surgir efeito de sentido ${ }^{19}$. Enaltece os valores humanos reconhecidos socialmente. É um jogo de linguagem de uma mesma gramática do olhar, caracterizada pelo registro figurativo, que explora e pela sintaxe interacional que utiliza.

“Nossa Missão, valor diferenciado, está no centro da nossa ação estratégica. Encontra-se nos pilares do foco do cliente, inovação e alto desempenho. Enquanto o nosso objetivo de longo prazo trata da busca por nossas metas, nossa missão reflete a realidade competitiva do mercado. Só obteremos sucesso nos negócios criando valor agregado para nossos clientes, nossos fornecedores, funcionários, acionistas e vizinhos. Criar um valor diferenciado significa construir relações mais fortes com os clientes e apresentar comportamentos orientados para a solução do cliente que podem se resumir na frase: Explorar, Descobrir, Criar e Entregar."

A narrativa da missão tem o intento de unificar a multiplicidade dos interpretantes atributivos, sintetizar os traços diferenciais do seu produto, e eleger o atributo considerado mais significativo. Reunir variadas qualificações em torno de um ponto de convergência virtual, ponto este que se situa num espaço possível e inusitado do universo linguístico-cultural. Associada ao $\operatorname{logo}$, o conjunto texto/ imagem opera importante mensagem com intenção de comunicar o caráter, a imagem e a personalidade da empresa como objeto valor, não apenas para o funcionário, mas também para o público externo ${ }^{20}$. Seus efeitos retóricos adquirem um caráter prático e popular que expressa a ideia, a imagem e o seu imediato reconhecimento pelo receptor.

O texto escrito fornece uma chave de sentido conduzindo a leitura da imagem e guiando a sua interpretação. A imagem é, por essência, polissêmica, ao passo que o texto escrito tem caráter mais unívoco; daí ser este o caminho para privilegiar um sentido possível, ou o sentido desejado e intencional. No plano da expressão o formante matérico da missão, apresenta-se

\footnotetext{
${ }^{18}$ IASBECK, L. C. A. (2002) A arte dos Slogans: as técnicas de construção das frases de efeitos do texto publicitários São Paulo: Annambule: Brasília: Upis. (pág.111)

${ }^{19}$ OLIVEIRA, A. C, Colóquio do Centro de Pesquisas Sociossemióticas, 2003, p.196.
} 
em um cartaz retangular que vai contrastar com a cor do logo. O eidético e o topológico vão homologar com o plano do conteúdo. O texto é, marcadamente, sedutor e convincente, diretivo e forte, como as cores e o estilo do logo.

As cores fortes e destacadas do logo em prospecção se mostram com o texto sobre o papel cromático amarelo claro. O enunciado busca o devir do sujeito, a conjunção, a dinâmica sugere movimento do $\log o$ com a persuasão do texto ${ }^{21}$. A estratégia midiática de textualização explorada em “... encontra-se nos pilares do foco do cliente, inovação e alto desempenho. Enquanto o nosso objetivo de longo prazo trata da busca por nossas metas, nossa missão reflete a realidade competitiva do mercado...", nos incita a olhar os valores ressaltados na atualidade.

O funcionário submetido à missão, sujeito de estado, se transforma em sujeito de fazer. A enunciação tem um efeito modificador nos estados do sujeito. A construção da imagem da empresa se faz conjunta com ele e o induz ao simulacro, dirige-se ao sujeito e instala-se em seu interior, já desnudado do invólucro que o protege: a sua identidade. A missão tem a função de divulgar valores que olham direto para o sujeito que anseia ser "modelo" 22. O funcionário contempla o objeto valor e transforma-se em sujeito actante, como segue:

"Só obteremos sucesso nos negócios criando valor agregado para nossos clientes, nossos fornecedores, funcionários, acionistas e vizinhos. Criar um valor diferenciado significa construir relações mais fortes com os clientes e apresentar comportamentos orientados para a solução do cliente que podem se resumir em: Explorar, Descobrir, Criar e Entregar".

As performances vocálicas acima citadas realçam e sugerem um convite a participar dessa competência. Esse aspecto adquire um poder de pregnância no destinatário, que automaticamente se põe em conjunção.

A função conotativa interage com as demais para atingir seu objetivo no sujeito que ali se encontra, em busca da competência que o sancione positivamente. Nesse enunciado, todas as funções prescritas jogam com a finalidade de tornar a comunicação efetiva; a eficácia da mensagem está na quantidade cumulativa de funções, ou na sua maior densidade, atuando simultaneamente para convencer os funcionários. A contaminação da comunicação "Criar um valor diferenciado, significa construir relações mais fortes..." é suficiente para produzir o efeito desejado.

A "Função Fática" aí presente chama a atenção para a própria mensagem, destacando o canal e não necessariamente a mensagem - mais pela sua forma do que pelo seu conteúdo. Ela é breve, compacta, afirma autoridade, pretende imprimir prestígio ao anunciado, é anônimo, causa impacto e pretende comunicação imediata dispensando reflexões demoradas. Essas características estão contidas na estrutura e não no que, eventualmente pretenda dizer.

A "Função Referencial" que pode ser explícita, dissimulada ou mesmo ausente, s ubstituída por expressões metalinguísticas, pode ser observada no

\footnotetext{
21 OLIVEIRA, A. C. M., "Notas sobre a presentificação: inteligibilidade e sensibilidade na primeira página do jornal", in Caderno de discussão VI Colóquio Centro de Pesquisas Sociossemióticas, 2000, pp. 177-188.

22 MORIN, E. Ciência com Consciência. Rio de Janeiro: Bertrand-Brasil, 1996, "Morin diz que a sociedade é um conjunto de homens com grupos de diversas dimensões e significados que unificados por algo maior que eles, compõem a humanidade".
} 
texto da missão. A presença da possibilidade da sua aplicação na empresa determina a força da mensagem. Ela não tem a finalidade de informar, deixa isso a cargo do texto argumentativo no seu todo: visão, objetivo e medidas de desempenho.

A função da frase no contexto é seduzir e motivar o destinatário à inserção. A referência é dissimulada por eufemismos e metáforas, "construir relações mais fortes...", pode servir a uma série infindável de ideias, mas aqui, especificamente, se refere à conjunção dos atores. A "informação" fala diretamente ao destinatário. Ultrapassa a própria missão para elevar o funcionário "conjunto com a empresa" com o seu diferencial, o nome da instituição, seu prestígio, sua solidez e demais atributos culturais relacionados ao seu produto. Aproxima o funcionário da referência "deslocada" do produto, de preferência os encantatórios.

A análise sócio semiótica do fragmento, "Só obteremos sucesso...", tem a intenção de construir junto e com, um perfil que nos dá a conhecer, se mostra e se oculta numa relação de sedução e tentação entre sujeito, observado e observador. A empresa e a sua missão nos olham de frente, é provocativa, seduz, se dá a conhecer insinuando que o sujeito é parte integrada, mas oculta a contra partida, "enquanto atendê-la integralmente". Sua impressão organiza-se num contínuo descontínuo, manipulador, provoca um querer fazer, para prender a atenção e o interesse do enunciatário: “... o nosso objetivo de longo prazo trata da busca por nossas metas, buscas audaciosas. Nossa missão reflete a realidade competitiva do mercado". Mas, isso só será possível se você enunciatário, se mantiver conjunto conosco.
As projeções actoriais e espaciais "Só obteremos sucesso nos negócios criando valor agregado para nossos clientes, nossos fornecedores, funcionários, acionistas e vizinhos", atuam como âncora que busca identificação e reconhecimento de elementos da narrativa por parte do enunciatário. As estratégias de textualização outorgam singularidade, que constroem procedimentos que apresentam mecanismos característicos, como o procedimento discursivo figurativo, o discurso temático e o discursivo enunciativo.

Os arranjos textuais “... Nossas medidas de desempenho reconhecem que o alto desempenho começa com funcionários engajados que enfocam os esforços na satisfação do cliente, e que testemunham nosso compromisso em comunidades habitáveis e sustentáveis...", variam conforme os procedimentos adotados pela enunciação. As estruturas semionarrativas e o modo como o texto narra a estratégia global é persuasiva. Ela desencadeia a tentação no enunciatário de vir a ser objeto valor e nesse momento provoca nele a aceitação do contrato proposto.

No contexto das atividades produtivas, a missão da empresa se insere no funcionário de uma forma dinâmica e ritual, atendendo a uma necessidade com a finalidade de compor a coletividade. A empresa utilizase dos artifícios da missão para criar efetivamente esse fenômeno. É importante entendê-la como linguagem diferenciada e verificar sua importância na sociedade moderna. Ela ultrapassa a mera função de informar. Coexistindo com as estratégias mercadológicas ela contamina e é contaminada. Assume o caráter de discurso que "joga para manter os mecanismos de 
hegemonia política do capitalismo mundial" 23 . Aí se singulariza, não só ideologicamente, como também esteticamente. Está presente nos manuais de administração das empresas que, geralmente, fazem parte do conhecimento cotidiano dos funcionários. A divulgação de ideias persuasivas tem nítidas intenções ideológicas. Explora o desenvolvimento da teoria dos sentidos, da percepção e traz o repertório de signos que se perfilam desde o século XVII com o desenvolvimento da industrialização. Esses signos correspondem a uma ideologia social e constituem uma forma de falar e representar no universo organizacional.

Como a missão tem a função de empolgar o destinatário, ela possui intenso grau emotivo. Ela sensibiliza a opinião com questões que valorizam a importância de caráter, procurando atingir o perfil do receptor previamente selecionado. Utilizase de termos e expressões que sugerem as práticas da sedução, "quer fazer parte da nossa equipe? Nós alimentamos o mundo". Neles, há uma dose reguladora de linguagem afetiva, "você quer alimentar o mundo?", nós ajudamos você em seus propósitos, mas para isso é preciso que se integre ao nosso corpo coletivo. Morin (1996) diz que "a sociedade é um conjunto de homens com grupos de diversas dimensões e significados que unificados por algo maior que eles, compõem a humanidade". A empresa é um micro da humanidade.
A função emotiva envolve conceitos culturais ligados aos valores muito explorados na atualidade como, a solidariedade, a não violência e a ecologia. A chamada "ser digno de confiança", inspira integridade na relação que construímos com o cliente. É um mecanismo verbal que objetiva o incitamento dos funcionários, compelindoos a um comportamento ativo e favorável à incorporação da mensagem.

"Nossas Medidas de Desempenho reconhecem que o alto desempenho começa com funcionários engajados que enfocam os esforços na satisfação do cliente, e que testemunham nosso compromisso em comunidades habitáveis e sustentáveis. E elas refletem que organizações que apresentam estes comportamentos terão o crescimento lucrativo necessário para sustentar o desempenho do tempo." Aqui a função incitativa caracteriza comunicação centrada no destinatário. A função gramatical mais pura da função conativa deixa de ser imperativo explícito, dissimulando a natureza incitativa em insinuações "sutis". O enunciado apresenta e anuncia que a empresa pensa à frente e é orientada pela ação, a função metalingüística tem a intenção de confirmar um código, e a função emotiva pelo caráter intersubjetivo da frase, propõe a cumplicidade afetiva. A função poética encontra-se na ruptura do paralelismo semântico. Por um lado provoca surpresa, e por outro, a perplexidade da liberdade de poder acrescentar algo positivo ao objeto valor ${ }^{24}$. “... reconhecemos que o alto desempenho dos funcionários proporciona satisfação ao nosso cliente."

A narrativa a seguir, nos remete a um todo harmônico, que supera sua origem comercial e seu fim imediato, introduzido nos rígidos limites do contrato algo

\footnotetext{
${ }^{23}$ IASBECK, L. C. A. A arte dos Slogans: as técnicas de construção das frases de efeitos do texto publicitários São Paulo: Annambule: Brasília: Upis. 2002.
} 
essencialmente humano ${ }^{25}$. “... Nossas medidas de desempenho reconhecem que o alto desempenho começa com funcionários engajados..., ... a visão da Cargill expressa as aspirações coletivas das pessoas que aqui trabalham. Ela nos unifica, dirige nossos esforços e nos diferencia..." Umberto $\mathrm{Eco}^{26}$ diz que a estética tem lugar na publicidade enquanto mecanismo retórico-persuasivo, que envolve e convence o homem a ação.

Sobre a conjunção texto/imagem, observando o logo indicando dinamismo e ação e o texto: “... a visão da empresa expressa as aspirações coletivas das pessoas que aqui trabalham...". Segundo Perez Tornero ${ }^{27}$, reaviva as distinções entre expressão e conteúdo. Promove o fazer criativo, com o saber e a operatividade do funcionário proporcionados pela missão da empresa, conforme segue:

"Perfil do Funcionário: A empresa encerrou 2001 apresentando, mais uma vez, um crescimento do seu quadro de funcionários, como conseqüência dos contínuos investimentos que estão sendo realizados para que a empresa aumente a sua participação nos mercados onde atua e esteja cada vez mais presente na vida de todo brasileiro. Durante 2001, o quadro de funcionários teve um aumento de $10,85 \%$. O quadro funcional feminino, por exemplo, aumentou 9\%. A Cargill fechou o ano com 5.057 funcionários. Deste total, $21 \%$ está na empresa há mais de dez anos".

Aqui observamos que dentre os valores que culturalmente são esperados de uma empresa, enfatiza que podemos relacionar: segurança, proteção, honestidade, garantia,

\footnotetext{
${ }^{25}$ MORIN, E. O Paradigma Perdido. Portugal: Europa América, 2000.

${ }^{26}$ ECO, Umberto.. I Limiti dell'Interpretazione. Milão Bompiani1999.

${ }^{27}$ PEREZ, T. Semiótica de la publicidad, Ed. Mitre. Barcelona, 1982
}

confiança, força, eficiência, presteza, entre outros. O nome de uma empresa em que predomine a função referencial de linguagem assume a forma afirmativa direta, e é escolhida entre as demais pelas qualidades desejáveis sendo eleita como a mais atraente: “... a visão da empresa expressa as aspirações coletivas das pessoas..., e. nosso objetivo é alimentar as pessoas". A empresa não faz a sua função sem as pessoas, ambas precisam uma da outra para possibilitar suas ações. De acordo com Morin (1999), todo indivíduo tem importância na empresa para a qual colabora com sua própria complexidade, sua visão do mundo, "seus projetos pessoais, suas atitudes imprevisíveis, as suas estratégias, sua dinâmica de evolução contribuem para a existência da empresa que é "a sua" representação da empresa".

As mensagens da missão são partes de um pressuposto e se dirigem a um público específico. Este público está predisposto captar as mensagens porque foi previamente selecionado, confinado em um espaço e submetido à cultura da empresa. A sua linguagem poética tende a elitizar o seu destinatário, por trabalhar com o mesmo paradigma "alimentar o mundo". Juntos poderão de forma eficiente atingir os seus objetivos, utilizando-se das características da linguagem referencial. A missão não visa apenas informar. Interessalhe, seduzir e cativar o destinatário em potencial das ideias veiculadas, a necessidade do comprometimento para o sucesso da empresa. Para conseguir a 
dosagem ideal deste comprometimento, ela trabalha um vasto repertório de estereótipos entendidos aqui como procedimentos paradigmatizantes já consagrados pela cultura e de fácil decodificação para o seu destinatário ${ }^{28}$.

Observamos que o texto atua na inferência por similaridade. Ele resultando em uma percepção intuitiva que, conjugado com o interesse do funcionário, provoca contiguidade sígnica, o ponto de partida para atuação da força dos metassignos. A metáfora tem, pois, a competência de iconizar sentidos em um processo eminentemente metalinguístico, no qual as palavras falam mais de si mesmas, chegando a esquecerem-se como signos primários.

\section{Considerações Finais}

De acordo com as investigações podemos concluir que a missão da empresa, texto mediador, e o funcionário, chegam a uma conjunção. A mediação da missão possibilita tamanha evolução nessa relação, que o funcionário vai além da representação de um papel. No processo de identificação com a empresa ele se transforma em sujeito, elevado a essa categoria pela ação da missão. O papel do texto da missão passa a se constituir em continuidade, e enuncivo destaca e fala ao funcionário como sujeito. Desta forma, o promove e determina o seu deslocamento, a sua hora de acordar, de levantar de se ligar e desligar. Participa com ele em condições de orientá-lo e de determinar a relação, e em todo o tempo, ambos permanecem alertas, vendo e sendo vistos. A missão da empresa costura todos os recursos que o homem precisa para se orientar. Entra em sua vida com tamanha impetuosidade que marca o seu cotidiano, governa o seu sentido e a sua presença, e mesmo quando ausente. Longe da empresa o homem mantém a sua forma de comunicação e interação, programada por ela.

A partir do texto da missão, homem e empresa unificam-se. Mais do que proximidade física integram-se. E com a tecnologia da comunicação, essa interação torna-se muito mais comprometida ${ }^{29}$. Nesse momento, o homem não apenas manuseia uma ferramenta apertando um parafuso permitido pela liberação das mãos, com o advento da hominização. Com as mãos livres, e competentes, o seu mundo de acesso vai muito além ${ }^{30}$. Metaforicamente ele passa a ter o mundo nas mãos através do poder, saber e fazer adquiridos.

O sedentarismo da empresa o aprisiona, e seduzido pelo espaço organizacional ele fica agregado. Espaço de comunhão dos diferentes iguais, diferentes personalidades e competências eficiências e conflitos, dirigidos pelo mesmo texto: a missão da empresa. Eles foram pescados no mercado de recursos humanos por profissionais que, estrategicamente, desenharam seus estereótipos e os classificaram como passíveis de adaptação. O seu perfil foi encaixado no cargo mais próximo ao adequado à sua personalidade, que

\footnotetext{
${ }^{28}$ FIORIN, J. L. Elementos da análise do discurso. São Paulo: Contexto, 1994.

${ }^{29}$ KAMPER, D.(1997). O trabalho como a vida, SP: Annablume.

${ }^{30}$ Norval Baitello. O animal que parou os relógios, 1997.
} 
selvagem, é domesticada a essa cultura. A empresa aprimora através de treinamentos os que atendem à sua necessidade, potencializando os traços coletivos. Ao entrar no sistema de ordem e se sedentarizar para trabalhar na linearidade, engessado às normas da empresa, ele abre mão de sua identidade. Incorpora a identidade coletiva, reproduz e se permite refém.

Mas, apenas permanecerão aí os nômades contaminados pela loucura da vaidade, da ambição e desejo de status, que atraídos por este cenário, vão consolidar e alimentar seus vínculos. O preço da sua permanência é a fratura, suspensão tensiva que gera uma anormalidade do comportamento. Gerada pela substituição da identidade e da mudança de constância, no ritmo de vida e de trabalho. Esse homem não mais poderá escolher, nem mesmo viver livremente, pois é governado pela missão. Missão promotora de transformação que desconstrói o pensamento do nômade que é livre e vive aos saltos, alguns não se permitem desconstruir. Esses que optam pela liberdade, a empresa descarta como excremento. E na definição de Kamper, o que pode transformar em imagem permanece, o resto naufraga ${ }^{31}$.

Nesses que naufragam observamos um fenômeno determinante que denuncia a sua capacidade de usar o seu livre arbítrio e fazer escolhas. $\mathrm{O}$ advento da loucura ${ }^{32}$. A esse fenômeno, Bateson denomina esquizofrenia, Foucault e Erasmo, de loucura, Dejours de sofrimento psíquico, e os psiquiatras de alteração ou desvio do comportamento, designado como padrão de normalidade. Resta-nos a pergunta: Qual normalidade?

\section{Referências Bibliográficas}

AGUILAR, G. Hernández (ed.), Sentido y significación (Puebla, Premia Edit., 1987).

BAITELLO, N. O animal que parou os relógios. SP: Annblume. 2a , ed 1999.

ECO, Umberto.. I Limiti dell'Interpretazione. Milão Bompiani1999.

FERRARA, Lucrecia. Os Significados Urbanos. São Paulo. Edusp/Fapesp 2000

FLUSSER, V. Natural:mente, Vários acessos ao significado de natureza - Ensaios. filosofia da natureza. São Paulo. Ed. D. cidades, 1979

HILLMAN, James. Encarando os deuses. São Paulo: Cultrix/Pensamento, 1997.

IASBECK, L. C. A. (2002) A arte dos Slogans: as técnicas de construção das frases de efeitos do texto publicitários São Paulo:

KAMPER, D. O trabalho como a vida, SP: Annablume.1997

KAMPER, Dietmar. Jan Fabre ou L'Art de L'Impossible. Strasbourg: La Chauferrie. 1999.

\footnotetext{
${ }^{31}$ KAMPER, Dietmar (1999). Jan Fabre ou L'Art de L'Impossible. Strasbourg: La Chauferrie.

${ }^{32}$ Flusser, V. Natural:mente, Vários acessos ao significado de natureza - Ensaios brasileiros, filosofia da natureza. São Paulo. Ed. D. cidades, 1979, "o homem é nômade, nasce nos vales e vai até os cumes para adquirir informações que o possibilite construir outros mapas mentais. Ele é livre para ficar ou retornar, mas se retornar jamais será integrado, porque possui outros mapas, assim, ele jamais se reintegrará, pois no cume é estrangeiro, e se retornar aos vales também ai o será porque partiu."
} 
LANDOWSKI, E., FIORIN, J. L. O gosto da gente o gosto das coisas. Abordagem semiótica. Trad. Brandão. E.São Paulo: EDUC/PUC, 1997.

LANDOWSKI, E. e OLIVEIRA, A. C. de (eds.), Do inteligível ao sensível, São Paulo, Educ, 1995.

MORIN, E. Introdução ao Pensamento Complexo. Lisboa: Inst. Piaget, 1990. "a convivência, só é possível em virtude da submissão dos indivíduos”.

MORIN, E. Ciência com Consciência. Rio de Janeiro: Bertrand-Brasil, 1996.

MORIN, E. O Método/ O conhecimento do conhecimento. Porto Alegre. Sulina, 1999.

MORIN, E. O Paradigma Perdido. Portugal: Europa América, 2000.

Norval Baitello. O animal que parou os relógios, 1997.

OLIVEIRA, A. C, Colóquio do Centro de Pesquisas Sociossemióticas, 2003, p.196.

OLIVEIRA, A. C., Eric Landowski, Caderno de Discussão do Centro de Pesquisa Sociossemiótica PUC: COS/USP/FFLCH/CNRS: PARIS, 2003.

OLIVEIRA, A.C. LANDOWSKI, E. Do inteligível ao sensível, São Paulo, Educ, 1995.

OLIVEIRA, A. C., LANDOWSKI, E. Caderno de Discussão do Centro de Pesquisa Sociossemiótica. São Paulo: ed. CPS. 2002. Annambule: Brasília: Upis. (pág.111).

OLIVEIRA, A. C. M., "Notas sobre a presentificação: inteligibilidade e sensibilidade na primeira página do jornal", Caderno de discussão VI Colóquio Centro de Pesquisas Sociossemióticas, 2000, pp. 177-188.

PEREZ, T. Semiótica de la publicidad, Ed. Mitre. Barcelona, 1982

PROSS, Harry, Estructura Simbolica del poder, 1980:36.

TEIXEIRA, L., "Relações entre o verbal e o não verbal: pressupostos teóricos", in Caderno de discussão do VII Colóquio do Centro de Pesquisas Sociossemióticas, 2000, pp. 415-426. WATZLAWICK, J. e JACKOBSON, D. Pragmática da comunicação Humana. São Paulo, Cultrix, 1993.

WEICK K. E. "The Significance of Corporate Culture." In: Org Culture. California: Sage. 1985.

WINKIN, Yves. A Nova comunicação. Da teoria ao trabalho de Campo. Campinas, Papiros. 1998. (Org. Etienne Samain). 